\title{
Feather loss and egg production in broiler breeders and layers
}

\author{
A.D. MILLS, J.M. FAURE and J.B. WILLIAMS \\ INRA, Station de Recherches avicoles \\ Centre de Recherches de Tours, Nouzilly, F 37380 Monnaie
}

\begin{abstract}
Summary
The relationships between various parameters of the laying cycle and feather loss from different parts of the body were studied in broiler breeders and layer hens. The pattern of feather loss was similar in both types of bird and was most pronounced on the breast. In both the broiler breeders and layers, there were significant negative correlations between overall feathering and egg production at 52 weeks of age and significant positive correlations between overall feathering and age at first egg. Other relationships between feathering and parameters of the laying cycle were more pronounced in the broiler breeders than in the layers, even though the former laid fewer eggs.
\end{abstract}

Key words : Domestic chickens, broiler breeders, layers, feather loss, egg production.

\section{Introduction}

Feather loss and plumage damage in caged domestic hens (Gallus gallus domesticus) are complex and controversial issues of considerable importance on both economic and welfare grounds (Hughes, 1985; Tind, 1985). When feathers are removed or damaged the insulation efficiency of the plumage is reduced and food intake increases (Emmans and Charles, 1977 ; Tauson and Svennson, 1980). Areas of exposed skin are more likely to be wounded or become infected, the removal of feathers involves pain or discomfort for the birds and birds with damaged plumage are aesthetically unattractive, which leads to adverse public opinion (HugHes, 1985). There is, therefore, a clear need to elucidate the factors which lead to feather loss. The present study was concerned with one particular aspect of this problem; the relationship between feather loss and egg production.

Various authors have reported that poor feathering is associated with higher egg output (Hughes, 1980 ; TAuson and Svensson, 1980 ; Tullett et al., 1980 ; Hughes, 1983). However, in most of these studies, only total egg output and overall feathering or total egg output and feathering of a limited number of body regions were considered. Furthermore, in all of these studies, only layer hens were used. The present study investigated feather loss from each of the various parts of the body and its relationship to different parameters of the laying cycle in both broiler breeders and layers. 


\section{Materials and methods}

\section{A. Animals and husbandry}

The animals used were 40 broiler breeder hens from the Station de Recherches avicole's $\mathrm{Z}$ line and 40 Isa-Brown layer hens. The $\mathrm{Z}$ line birds were obtained from the Station's breeding flock and were hatched at the Station. The Isa-Brown birds were obtained as day old chicks from a commercial supplier. From day old to 18 weeks of age the birds were housed, in single strain groups, in floor pens. When the birds were 18 weeks of age they were weighed and then transferred to individual cages located on the middle tiers of three tier battery cage units. The broiler breeders and layers were housed in separate cage units, but both cage units were located in the same poultry house. The lighting regimen in the poultry house was 14 hours of light to 10 hours of darkness. The temperature in the poultry house was artificially regulated at $20 \pm 2{ }^{\circ} \mathrm{C}$. Food and water were available ad libitum to the layer hens. Water was available ad libitum to the broiler breeder hens but their food intake was limited to $150 \mathrm{~g}$ per day. All birds were fed the Station's standard layer diet (Leclerce et al., 1984). The date on which each hen laid her first egg was recorded. Thereafter, a daily record of egg production was kept for each bird until it was 52 weeks of age.

\section{B. Assessment of plumage condition}

Plumage condition was assessed, when the birds were 52 weeks of age, using a system modified from that described by TAUSON (1977). Under this system each bird was individually examined and given a feathering score of 1 to 4 for each of five parts of the body (breast and crop, neck, wings, dorsum, and tail) with 4 as the best (i.e. perfect or near perfect plumage) and 1 as the worst (i.e. total defeathering or extreme feather damage). Thus, each animal had a feathering score of 1 to 4 for each region of the body and a global feathering score (i.e. the sum of the feathering scores for all parts of the body) from 5 to 20 .

\section{Parameters of the laying cycle}

The following parameters of the laying cycle was calculated for each bird with the exception of one broiler breeder hen which laid only six eggs during the experimental period :

1. Age (days) at first egg.

2. Age (days) at peak of lay. Peak of lay was defined as the mid-point of the 28 days of greatest egg production.

3. Egg production at peak of lay (i.e. egg production during the 28 days of greatest egg production).

4. Egg production during $I_{1}$. $I_{1}$ was defined as the period between the day on which the first egg was laid and the peak of lay.

5. Egg production during $I_{2}$. $I_{2}$ was defined as the 137 days following the peak of lay. 
6. Egg production during $I_{3} . I_{3}$ was defined as the 112 days following $I_{2}$.

7. Total egg production at 52 weeks of age.

Egg production at peak of lay and during $I_{1}, I_{2}$ and $I_{3}$ were expressed as percentage production per hen day (i.e. number of eggs laid/number of days $\times 100$ ).

\section{Results}

At 18 weeks of age the mean ( \pm SEM) weight of the broiler breeders was 2.21 $( \pm 0.04) \mathrm{kg}$ and that of the layers was $1.46( \pm 0.03) \mathrm{kg}$. This difference was significant ( $\mathrm{P}<0.05 ; 2$-tailed ' $\mathrm{t}$ ' test). Table 1 shows the mean ( \pm SEM) values for the various parameters of the laying cycle in the broiler breeders and layers respectively. The broiler breeders were inferior to the layers in respect of all of the parameters of the laying cycle measured.

\section{TABLE 1}

Parameters of egg production in broiler breeders and layers.

Paramètres de ponte chez des pondeuses et des reproductrices chair.

\begin{tabular}{|c|c|c|}
\hline $\begin{array}{l}\text { Parameter of egg production } \\
\text { Paramètres de ponte }\end{array}$ & $\begin{array}{l}\text { Broiler breeders } \\
\text { Reproductrices chai } \\
(\mathrm{n}=39)\end{array}$ & $\begin{array}{l}\text { Layers } \\
\text { Pondeuses } \\
(\mathrm{n}=40)\end{array}$ \\
\hline $\begin{array}{l}\text { Age (days) at 1st egg } \ldots \ldots \ldots \\
\text { Age (jours) au } 1^{\text {er }} \text { ouf }\end{array}$ & $170.50( \pm 1.10) *$ & $149.85( \pm 0.97)$ \\
\hline $\begin{array}{l}\text { Age (days) at peak lay ........ } \\
\text { Age (jours) au pic de ponte }\end{array}$ & $204.89( \pm 2.77)$ & $189.45( \pm 3.95)$ \\
\hline $\begin{array}{l}\% \text { production during } \mathrm{I}_{1} \ldots \\
\% \text { production pendant } I_{1}\end{array}$ & $75.41( \pm 2.33)$ & $87.18( \pm 1.47)$ \\
\hline $\begin{array}{l}\% \text { production during } I_{2} \ldots \ldots \\
\% \text { production pendant } I_{2}\end{array}$ & $59.85( \pm 3.16)$ & $84.55( \pm 2.07)$ \\
\hline $\begin{array}{l}\% \text { production during } \mathrm{I}_{3} \ldots \ldots \\
\% \text { production pendant } \mathrm{I}_{3}\end{array}$ & $42.03( \pm 3.71)$ & $75.58( \pm 2.51)$ \\
\hline $\begin{array}{l}\% \text { production at peak lay. ...... } \\
\% \text { production au pic de ponte }\end{array}$ & $80.69( \pm 1.26)$ & $95.90( \pm 1.28)$ \\
\hline $\begin{array}{l}\text { Egg production at } 52 \text { weeks } \ldots \\
\text { Ponte à } 52 \text { semaines }\end{array}$ & $75.80( \pm 4.21)$ & $150.80( \pm 3.51)$ \\
\hline
\end{tabular}

Values are means $( \pm$ SEM $){ }^{*}$ denotes a significant $(P<0.05)$ difference between broilers and layers $(2-$ tailed $\mathrm{t}$ tests).

Les valeurs sont les moyennes ( \pm l'écart-type à la moyenne). ${ }^{*}$ dénote une différence significative $(P<0,05)$ entre les poules reproductrices chairs et les poules pondeuses (test bilatéral de $t$ ).

Table 2 shows the mean ( \pm SEM) feathering scores of the broiler breeders and layers respectively. Global feather condition did not differ between the two types of bird but the broiler breeders had significantly lower feathering scores for the wings than the layers. In both types of bird feathering scores for the breast were significantly lower than for other parts of the body. 
TABLE 2

Feather scores for the breast, wing, neck, dorsum and tail of 52 week old broilers breeders and layers.

Note de plumage pour la poitrine, les ailes, le cou, la région dorsale et la queue chez les poules pondeuses et reproductrices chair de 52 semaines d'âge.

\begin{tabular}{|c|c|c|}
\hline & \multicolumn{2}{|c|}{ Feather score - Note de plumage } \\
\hline & $\begin{array}{l}\text { Broilers - Chair } \\
\quad(\mathrm{n}=40)\end{array}$ & $\begin{array}{c}\text { Layers - Pondeuses } \\
\quad(\mathrm{n}=40)\end{array}$ \\
\hline Neck - Cou . . . . . . . . . & $3.85( \pm 0.06) \mathrm{a}$ & $3.56( \pm 0.14) \mathrm{ac}$ \\
\hline Breast - Poitrine & $2.38( \pm 0.18) b$ & $2.55( \pm 0.13) b$ \\
\hline Wings - Ailes . & $2.83( \pm 0.14) b^{*}$ & $3.63( \pm 0.09) \mathrm{a}+$ \\
\hline Dorsum - Dos & $3.80( \pm 0.07) \mathrm{a}$ & $3.93( \pm 0.04) \mathrm{c}$ \\
\hline Tail - Queue. & $3.33( \pm 0.12) \mathrm{c}$ & $3.40( \pm 0.09) \mathrm{d}$ \\
\hline Global - Global & $16.18( \pm 0.39)$ & $17.03( \pm 0.28)$ \\
\hline
\end{tabular}

Values are means $( \pm$ SEM). Within columns values bearing different letter differ significantly at least at $P<0.05$. Within rows values bearing different symbols differ significantly at least at $\mathrm{P}<0.05$. $\mathrm{P}$ values were obtained from analysis by the Mann-Withney $U$ test (2-tailed).

Les valeurs sont les moyennes ( \pm écart-type à la moyenne). A l'intérieur d'une même colonne les valeurs suivies de lettres différentes sont significativement différentes $(P<0,05)$. A l'intérieur d'une même ligne les valeurs suivies de symboles différents sont significativement sifférentes $(P<0,05)$. Les valeurs des probabilités d'hypothèse nulle sont calculées par un test bilatéral de Mann et Withney.

\section{TABLE 3}

Egg production at 52 weeks of age and its relationship to the global feather score and feather scores for the breast, wing, neck, dorsum and tail of 52 week old broilers and layers.

La ponte à 52 semaines d'âge et ses relations avec la note d'emplumement global et les notes d'emplumement pour la poitrine, les ailes, le cou, la région dorsale et la queue chez les poules pondeuses et reproductrices chair.

\begin{tabular}{|c|c|c|}
\hline \multirow{2}{*}{$\begin{array}{c}\text { Feather score } \\
\text { Note d'emplumement }\end{array}$} & \multicolumn{2}{|c|}{$\begin{array}{l}\text { Correlation coefficient } \\
\text { Coefficient de corrélation }\end{array}$} \\
\hline & $\begin{array}{l}\text { Broiler breeders } \\
\text { Reproductrices chair }\end{array}$ & $\begin{array}{c}\text { Layers } \\
\text { Pondeuses }\end{array}$ \\
\hline Neck - Cou . . . . . & -0.21 & -0.13 \\
\hline Breast - Poitrine .... & $-0.65^{*}$ & -0.24 \\
\hline Wings - Ailes . . . . . & $-0.43^{*}$ & $-0.39^{*}$ \\
\hline Dorsum - Région dorsale & $-0.33^{*}$ & -0.09 \\
\hline Tail - Queue . . . . . . & -0.05 & -0.23 \\
\hline Global - Global & $-0.54^{*}$ & $-0.37^{*}$ \\
\hline
\end{tabular}

Values are Spearman rank correlation coefficients. ${ }^{*}: \mathbf{P}<0.05 .(1-$ tailed $)$.

Les valeurs sont les coefficients de corrélation de Spearman. ${ }^{*}: P<0,05$. (Test unilatéral). 
Table 3 shows the correlations between feathering scores for various parts of the body and total egg production at 52 weeks of age. In both types of bird there were significant negative correlations between global feathering score and egg production at 52 weeks of age and between wing feathering scores and egg production at 52 weeks of age. However, in the layers all other correlations were non-significant, whereas in the broiler breeders significant negative correlations also existed between feathering scores for the breast and tail respectively and egg production at 52 weeks of age.

Table 4 shows the correlations between the various parameters of the laying cycle and global feathering scores in the broiler breeders and layers. In both types of bird there was a significant positive correlation between age at first egg and global feathering score and a significant negative correlation between egg production at 52 weeks and global feathering score. However, in the layers all other correlations were nonsignificant ; whereas in the broiler breeders age at peak of lay, production during $\mathbf{I}_{1}$, production during $I_{3}$ and production at peak of lay were in significant negative correlation with global feathering score.

\section{TABLE 4}

Correlations between various parameters of egg production and global feather score in broiler breeders and layers.

Corrélations entre les différents paramètres de ponte et la note d'emplumement global chez des pondeuses et des reproductrices chair.

\begin{tabular}{|c|c|c|}
\hline \multirow{2}{*}{$\begin{array}{l}\text { Parameter of egg production } \\
\text { Paramètres de ponte }\end{array}$} & \multicolumn{2}{|c|}{$\begin{array}{l}\text { Correlation coefficient } \\
\text { Coefficients de corrélation }\end{array}$} \\
\hline & $\begin{array}{l}\text { Broiler breeder } \\
\text { Reproductrices chair }\end{array}$ & $\begin{array}{l}\text { Layers } \\
\text { Pondeuses }\end{array}$ \\
\hline $\begin{array}{l}\text { Age (days) at 1st egg } \cdots \cdots \\
\text { Age (jours) au } I^{e r} \text { ouf }\end{array}$ & $+0.43^{*}$ & $+0.27^{*}$ \\
\hline $\begin{array}{l}\text { Age (days) at peak lay ....... } \\
\text { Age (jours) au pic de ponte }\end{array}$ & $-0.35^{*}$ & -0.10 \\
\hline $\begin{array}{l}\% \text { production during } \mathrm{I}_{1} \ldots \ldots \ldots \\
\% \text { production pendant } I_{1}\end{array}$ & $-0.50^{*}$ & -0.24 \\
\hline $\begin{array}{l}\% \text { production during } \mathrm{I}_{2} \ldots \ldots \ldots \\
\% \text { production pendant } \mathrm{I}_{2}\end{array}$ & -0.07 & +0.07 \\
\hline $\begin{array}{l}\% \text { production during } \mathrm{I}_{3} \ldots \ldots \ldots \\
\% \text { production pendant } \mathrm{I}_{3}\end{array}$ & $-0.40^{*}$ & -0.07 \\
\hline $\begin{array}{l}\% \text { production at peak lay. ..... } \\
\% \text { production au pic de ponte }\end{array}$ & $-0.32^{*}$ & -0.11 \\
\hline $\begin{array}{l}\text { Egg production at } 52 \text { weeks. } \\
\text { Ponte à } 52 \text { semaines }\end{array}$ & $-0.54^{*}$ & $-0.37^{*}$ \\
\hline
\end{tabular}

Values are Spearman rank correlation coefficients. ${ }^{*}: \mathrm{P}<0.05 .(1-$ tailed)

Les valeurs sont les coefficients de corrélation de Spearman. ${ }^{*}: P<0,05$. (Test unilatéral).

\section{Discussion}

With the exception of the wings, the feather scores of the broiler breeders and layers did not differ significantly, implying that the pattern of feather loss was similar in both types of bird, despite their differing size and laying performance. In both the 
broiler breeders and layers, feather loss was significantly greater from the breast than from other regions of the body. This last finding is consistent with those of Hughes (1983) and BESSEI (1984) for other strains of layer hens. Thus, it would appear that, at least in birds caged individually, feather loss is most pronounced on the breast in both broiler breeder and layer hens.

In both types of bird there was a negative relationship between total egg production at 52 weeks of age and overall feathering. This finding is also consistent with the results of previously published studies of layer hens (Hughes, 1980 ; TAuson and Svensson, 1980 ; Tulletr et al., 1980 ; Hughes, 1983) and extends the generality of this phenomenon to broiler breeder hens. However, since this relationship (and the relationships between overall feathering and other parameters of the laying cycle) appeared to be more pronounced in the broiler breeders than the layers, even though the former laid fewer eggs, these findings must be considered within the framework of existing theories of feather damage and loss in caged hens; and more particularly in relation to Hughes's $(1980 ; 1985)$ conclusion that abrasion, which occurs during the expression of pre-laying behaviour, contributes substantially to breast feather damage and loss in individually caged hens.

As Hughes (1985) points out «the most controversial aspect of feather damage and loss in cages is undoubtedly whether it is caused by abrasion or by feather pecking ». When birds are caged in groups, inter-bird pecking, in which birds remove feathers from one another, is likely to outweigh, or least to mask, feather damage or loss attributable to abrasion (TIND, 1985). However, when birds are caged individually, although the possibility that hens may have their feathers removed by birds in adjacent cages (Hill and BallaNTYNe, 1980 ; Hughes, 1980 ; 1985) cannot be wholly ignored, it seems likely that auto- or self-pecking, in which birds remove their own feathers (SANGer and Hamdy, 1962 ; Hill, 1980), and abrasion are the major cause of feather damage and loss (Hughes, 1985).

In his review of the causation of feather loss and damage in caged birds, Hughes (1985) concluded that feather damage on some regions of the body (notably the breast) is consistent with abrasion due to rubbing against the sides and/or floor of the cage during the performance of pre-laying behaviour patterns, such as stereotyped escape behaviour (WoOd-Gush, 1972 ; MiLls and Wood-Gush, 1985) and vacuum nestbuilding behaviour (MILLS and WooD-GuSH, 1985) ; whereas damage on other parts of the body (such as the back), which are unlikely to come into contact with the cage, is probably attributable to self-pecking. Evidence in support of the link between prelaying behaviour and feather damage or loss from certain regions of the body, suggested by HugHes $(1980,1985)$, comes from several sources. These are :

Firstly, the existence of a positive relationship between egg production and feather loss - particularly from the breast (Hughes, 1980 ; 1983 ; TAuson and SvensSON, 1980 ; TUlletT et al., 1980). Laying hens present high plasma oestrogen levels which are known to inhibit feather growth (Lucas and STETTENheim, 1972 ; PAYNe, 1972 ; JohNson, 1986) and birds which lay the most eggs are those which are most likely to suffer feather loss due to abrasion during pre-laying bahaviour. Thus it is possible to envisage feathers being lost progressively during the laying cycle as a consequence of pre-laying behaviour and failing to be replaced because of the hormonal status of the birds. Such an effect would lead to indirect positive relationship between feather loss and egg production. 
Secondly, feather loss from the breast is heritable (BESSEI, 1984) and certain elements of pre-laying behaviour, which might contribute to the occurrence of abrasion, are also heritable (Mills et al., 1985).

Thirdly, replacing wire mesh partitions between cages with smooth sheets reduces feather damage and loss, presumably because of reduced abrasion (TAuson, 1977 ; Hill, 1980 ; Hughes and Michie, 1982).

The findings of this study are consistent with the first of the three lines of evidence described above. Firstly, in both the broiler breeders and layers, there were significant negative correlations between overall feathering and egg production at 52 weeks of age. Secondly, in both types of bird, feather damage was most pronounced on the breast and wings; such damage is consistent with abrasion during pre-laying behaviour. Furthermore, such damage was significantly correlated with egg production at 52 weeks in the broiler breeders and significantly correlated (wings) or almost significantly correlated (breast ; $\mathrm{P}=0.07$ ) with egg production at 52 weeks in the layers. Thirdly, in both types of bird, there was a significant positive correlation between age at first egg and overall feathering; thus the birds which came into lay first, and therefore expressed pre-laying behaviour over the longest period, showed the greatest feather damage. Fourthly, the relationships between overall feathering and the various parameters of egg production measured were stronger in the broiler breeders than in the layers, even though the former laid fewer eggs. This implies that egg production is not directly related to feather loss but rather that there is a variable link between these two traits. Pre-laying behaviour would appear to meet the requirements of this link.

In conclusion, the results of this support Hughes's $(1980 ; 1985)$ conclusion that feather loss and egg production in laying hens are linked by abrasion which occurs during the expression of pre-laying behaviour and extend this observation to broiler breeder hens. Furthermore, because the relationships between feather loss and egg production were stronger in the broiler breeders than the layers, despite the former's inferior laying performance, it is possible to make certain predictions concerning prelaying behaviour and egg production in the two types of bird. Firstly, at least within the strains used here, broiler breeder hens should present more pre-laying behaviour associated with abrasion than layer hens and/or, perhaps because of their larger size, rub against the sides of the cage more than layers during such behaviour. Secondly, within strains, the amount of abrasion related pre-laying behaviour should, if weighted for egg output, correlate positively with feather loss. Verification of either or both of these predictions would further support the notion (HUGHEs, 1980 ; 1985) that egg production and feather loss are linked through pre-laying behaviour.

Reçu en juin 1988.

Accepté en août 1988.

\section{Acknowledgement}

An anonymous referee is thanked for comments which contributed greatly to the final version of the manuscript. 


\author{
Résumé \\ La perte des plumes et ses relations avec la ponte \\ chez les pondeuses et les reproductrices chair
}

La perte des plumes sur les différentes parties du corps et ses relations avec la ponte ont été étudiées chez des poules pondeuses et des reproductrices chair. La perte des plumes était presque identique dans les deux types de poules et était maximale sur la poitrine. Chez les reproductrices chair et les pondeuses, des corrélations négatives significatives ont été trouvées entre l'emplumement global et la ponte à 52 semaines et des corrélations positives significatives entre l'emplumement global et l'âge au premier ouf. Les autres relations entre la perte des plumes et les paramètres de ponte étaient plus prononcées chez les reproductrices chair que chez les pondeuses, même si les premières ont pondu moins d'œufs.

Mots clés : Poule domestique, pondeuses, reproductrices chair, perte des plumes, ponte.

\title{
References
}

BESSEI W., 1984. Genetische beziehungen zwischen Leistung, Befiederung und Scheu bei Legenhennen. Arch. für Geflugelk., 48, 231-239.

Emmans G.C., Charles D.R., 1977. Climatic environment and poultry feeding in practice. In : Nutrition and the climatic environment. Eds. Haresign, W., Swan, H., Lewis, D., pp. 31-49. Butterworths, London.

HILl J.A., 1980. Feather loss in layers. Gleadthorpe Experimental Husbandry Farm Booklet $n^{\circ} 7$, Ministry of Agriculture Fisheries and Food, London.

Hill J.A., Ballantyne A.J., 1980. The effect of solid sided V open sided and backed cages on feather cover and performance of laying fowls. Unpublished Ministry of Agriculture, Fisheries and Food Report FAC. 383 (pultry). Cited in : Hughes, B.O. 1985. Feather loss - How does it occur? In : Proc. 2nd European Symposium on Poultry Welfare. Ed. Wegner, R.M., pp. 177-188. German Branch of the W.P.S.A., 1985.

Hughes B.O., 1980. Feather damage in hens caged individually. Brit. Poult. Sci., 21, 149-154.

Hughes B.O., 1983. The effects of methionine and egg production on feather loss in caged layers. Brit. Poult. Sci., 24, 549-553.

Hughes B.O., 1985. Feather loss - How does it occur ? In : Proc. 2nd European Symposium on Poultry Welfare. Ed. Wegner R.M., pp. 177-188. German Branch of the W.P.S.A., 1985.

Hughes B.O., MichiE W., 1982. Plumage loss in medium bodied hybrid hens. The effect of beak trimming and cage design. Brit. Poultry Sci., 23, 59-64.

Johnson A.L., 1986. Reproduction in the female. In : Avian Physiology, 4th Edition. Ed. Sturkie, P.D., pp. 403-431, Springer-Verlag, New York, Berlin, Heidelberg, Tokyo, 1986.

Leclerce B., Blum J.C., Sauveur B., Stevens P., 1984. Alimentation des poules pondeuses. In : L'alimentation des animaux monogastriques : porc, lapin, volailles. INRA, Paris, 1984, pp. 95 104.

LuCAS A.M., Stettenheim P.R., 1972. Avian Anatomy, Integument : Part 2. pp. 341-420, U.S. Government Printing Office, Washington, 1972.

Mills A.D., Wood-Gush D.G.M., 1985. Pre-laying behaviour in battery cages. Brit. Poultry Sci., 26, $247-252$.

Mills A.D., Wood-Gush D.G.M., Hughes B.O., 1985. Genetic analysis of strain differences in pre-laying behaviour in battery cages. Brit. Poultry Sci., 26, 187-197.

PAYNE R.B., 1972. Mechanisms and control of moult. In : Avian Biology, Vol. 2 Eds. Farner, D.S. and King, J.R., pp. 103-155, Academic Press, London, 1972. 
SANGer V.L., Hamdy A.H., 1962. A strange fright/flight behaviour pattern (hysteria) in hens. J. Amer. Vet. Med. Assoc., 140, 455-459.

TAUSON R., 1977. The influence of different technical environments on the performance of laying hens. Report $n^{\circ}$ 49. Swedish Univ. Agric. Sci., Dept. Anim. Husbandry, 75007 Uppsala, Sweden.

Tauson R., Svennson S.A., 1980. Influence of plumage condition on the hen's feed requirement. Report $n^{\circ}$ 77. Swedish Univ. Agric. Sci., Dept. Anim. Husbandry, 75007 Uppsala, Sweden.

Tind E., 1985. Feather loss: the effects of abrasion. In : Proc. 2nd European Symposium on Poultry Welfare. Ed. Wegner R.M., pp. 189-200. German Branch of the W.P.S.A., 1985.

Tullett S.G., Macleod M.G., Jewitr T.R., 1980. The effects of partial defeathering on energy metabolism in the laying fowl. Brit. Poult. Sci., 21, 241-245.

Wood-Gush D.G.M., 1972. Strain difference in response to suboptimal stimuli in the fowl. Anim. Behav., 20, 72-76. 